Portland State University

PDXScholar

\title{
Homoeroticism and Thomas Mann's Death in Venice
}

Thomas Winston Morgan

Portland State University

Follow this and additional works at: https://pdxscholar.library.pdx.edu/open_access_etds

Part of the German Language and Literature Commons Let us know how access to this document benefits you.

Recommended Citation

Morgan, Thomas Winston, "Homoeroticism and Thomas Mann's Death in Venice" (1994). Dissertations and Theses. Paper 4798.

https://doi.org/10.15760/etd.6681

This Thesis is brought to you for free and open access. It has been accepted for inclusion in Dissertations and Theses by an authorized administrator of PDXScholar. Please contact us if we can make this document more accessible: pdxscholar@pdx.edu. 


\section{THESIS APPROVAL}

The abstract and thesis of Thomas Winston Morgan for the Master of Arts in German were presented June 22, 1994, and accepted by the thesis committee and the department.

COMMITTEE APPROVALS:

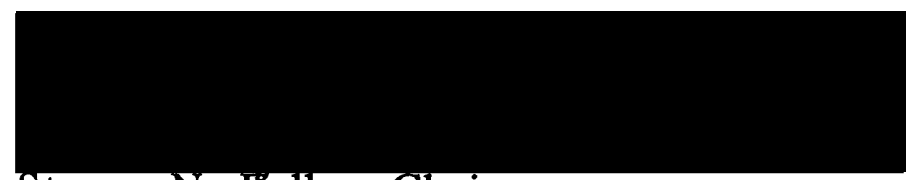

Steven N. Fuller, Chair

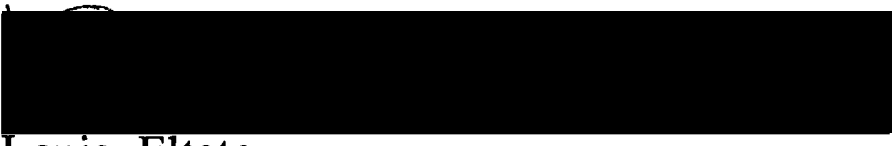

Louis Elteto

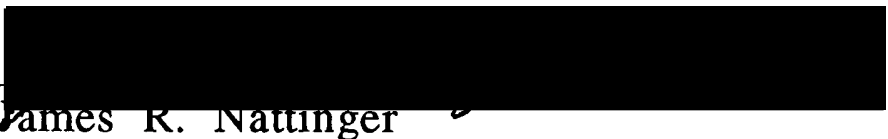

Representative of the Office of

Graduate Studies

DEPARTMENT APPROVAL:

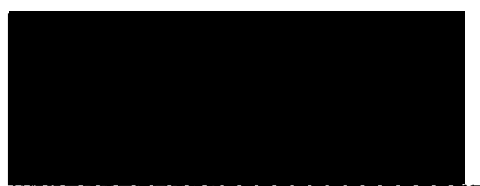

Linda Parshall, Chair

Department of Foreign Languages and Literatures

$* * * * * * * * * * * * * * * * * * * * * * * * * * * * * * * * * * * * * * * * * * * * * * * * * * * * * * * * * * * * * * * * * * * * * *$

ACCEPTED FOR PORTLAND STATE UNIVERSITY BY THE LIBRARY

by

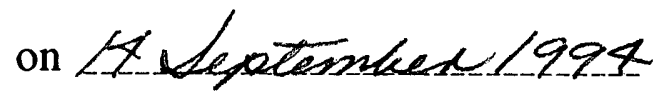




\begin{abstract}
An abstract of the thesis of Thomas Winston Morgan for the Master of Arts in German presented June 22, 1994.
\end{abstract}

Title: Homoeroticism and Thomas Mann's Death in Venice

In the late 1970 s and early 1980 s, previously unpublished portions of Thomas Mann's diaries were released for publication. These excerpts contained passages that removed all previous doubt as to Mann's sexual proclivities, affirming his homosexual inclinations. It had been suspected that Mann was homosexual before this time, but there was no conclusive proof until the release of the now-famous (or infamous) diary entries. Now that there is written proof of Mann's sexual orientation, literary scholars can more persuasively argue the often overlooked or circumvented homosexual aspects of his writings.

This thesis is an investigation of the homoerotic elements in Thomas Mann's novella, Death in Venice. The present study draws out the homoerotic elements of the text and places them in a socio-historical context. Textual analysis, as it concerns coded homosexual desire, as well as a biographical schema of Mann highlight the homoerotic characterizations in the novella. The analysis is based in an historical context, a time when homosexual expression was strictly illegal. The tension created between 
Mann's need to process his homosexuality and his internal moral code - as well as the external moral code of Wilhelmine Germany - forced him to contrive a story in which he could only present homosexual desire in code or via allusions to the homosexuality of Ancient Greece. 


\title{
HOMOEROTICISM AND THOMAS MANN'S \\ DEATH IN VENICE
}

\author{
by \\ THOMAS WINSTON MORGAN
}
A thesis submitted in partial fulfillment of the requirements for the degree of
MASTER OF ARTS
in
GERMAN

Portland State University

1994 


\section{DEDICATION}

To my partner, Stephen. 
TABLE OF CONTENTS

PAGE

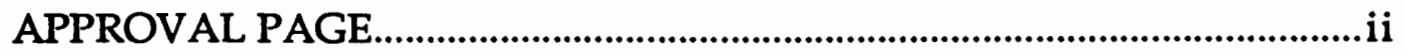

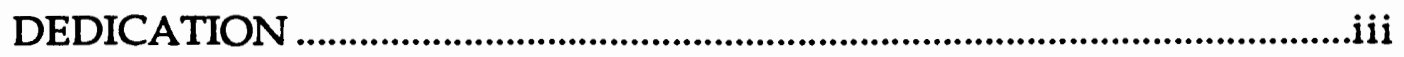

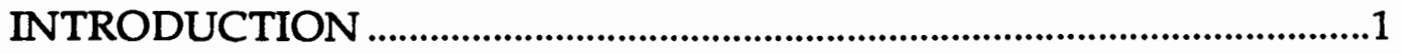

HOMOEROTICISM AND DEATH IN VENICE .......................................12

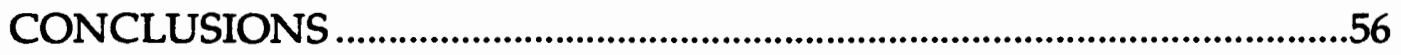

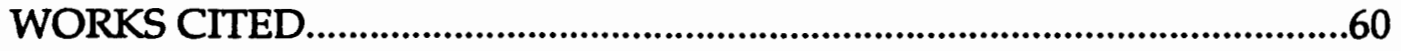




\section{INTRODUCTION}

In 1993 the United States Congress held hearings to decide whether the government would allow homosexuals to live and serve openly in the Armed Forces. The issue was divisive and contentious. During the hearings some congressional members openly supported homosexuals' full rights in all segments of society, including the military. Others vehemently opposed the integration of openly gay and lesbian service people. These representatives resorted to stereotypes of sexual predation and sickness to defend their position that military service and homosexuality were incompatible. The hearings permeated the American media. In nearly every major newspaper on any given day during the hearings, one would confront an article, news brief or editorial concerning homosexuals in the military. Many news accounts branded the hearings a travesty, charging they were degrading to those homosexuals who had had the courage to testify.

Numerous editorial writers and congressional representatives stated those who testified had been publicly vilified and belittled. While perhaps true about this specific event, the hearings were a public wrangle, symptomatic of a larger and more pervasive cultural war over the integration of homosexuals into society. A single issue had set the stage on which a much larger debate took place.

The United States is not unique in this respect. A similar phenomenon occured in Germany in the early 1900's. A major scandal, later 
known as the Eulenburg affair, gripped the country and tested the limits of the German's sexual tolerance. "From 1907 to 1909, Imperial Germany was rocked by a series of courts-martial concerned with homosexual conduct in the army as well as five courtroom trials that turned on the homosexuality of prominent members of Kaiser Wilhelm II's entourage and cabinet." 1 The social climate regarding homosexuality in Germany in the early part of this century was one of extreme intolerance. Perhaps no other incident manifests this social phenomenon better than the Eulenburg affair. The Eulenburg scandal, like the debate in the United States, tore through the country's press. Homosexuality was discussed in detail - public discussions including the mechanics of homosexual lovemaking. Despite the negative and furious debate on homosexuality, with its sordid anti-gay representations, the affair did increase the public's awareness of homosexuality, forcing "[...] individuals to reconceptualize their sexual activities and thus contributing to the making of modern homosexuals." 2 Headway was made in the struggle for homosexual emancipation in that the issue was so widely publicized. The general public now had to confront the issue and its own biases. As never before, the Eulenberg affair and the ensuing public debate polarized two very distinct camps, making feelings manifest that until the time of the affair had been latent in Germany. The two camps consisted of a

1 James D. Steakley, "Iconography of a Scandal: Political Cartoons and the Eulenburg Affair in Wilhelmine Germany," Hidden From History: Reclaiming the Gay \& Lesbian Past, ed. Martin Bauml Duberman, Martha Vicinus, and George Chauncey,Jr. (Ontario: NAL Books, 1989) 233. All of the details of the Eulenburg Affair are from Steakley's essay.

2 Steakley 233. 
conservative, anti-gay contingent and the beginnings of a modern German homosexual rights movement.

The principal fight for homosexual emancipation in Germany surrounded the attempt to repeal a far-reaching sodomy law, the infamous Paragraph 175. 3 This Paragraph was an anti-homosexuality edict forbidding all "deviant" sexual advances and acts between men. Although Paragraph 175 applied only to male homosexuality, the:

[...] wave of anti-homosexual sentiment stirred up by the [scandal] along with reaction against the women's emancipation movement led in late 1909 to the introduction of a draft penal code which ignored previous reform efforts and even extended Paragraph 175 to homosexual acts between women. 4

Thus, German homosexuals considered the repeal of Paragraph 175 to be a basic step if social justice were to advance. At the forefront of this fight was Magnus Hirschfeld - a Jewish physician from Berlin. Hirschfeld organized the Wissenschaftlich-Humanitäres Committee, a clearinghouse for political and medical information on homosexuality. Hirschfeld attacked anti-gay propaganda by attempting to eradicate rampant misinformation. He and his committee wrote and published countless essays and scientific papers on homosexuality. Hirschfeld advocated a theory of homosexuals belonging to a third sex. His was a medical approach, with the goal of furthering

\footnotetext{
3 The history of Paragraph 175 can be found in James D. Steakley, The Homosexual Emancipation Movement in Germany (Salem: Ayer, 1975).

4 Steakley 40.
} 
acceptance of homosexuals as simply another variant in the spectrum of human sexuality.

Despite Hirschfeld's early efforts, and despite the implications of blatant persecution of homosexuals during the Nazi regime, Paragraph 175 remained in effect until 1961. The majority of German legislators, before or after World War II, were not willing to end discrimination against homosexuals, despite their knowledge of the systematic pursuit and extermination of countless gay men and lesbians during the Nazi period. The objectification and marginalization of homosexuals was simply too pervasive. Homosexuality persisted as a principal target for Germany's rightwing conservatives during the early 1900's. In whatever forum the issue of homosexuality appeared, be it politics, newspapers, or even in literature, social conservatives mounted an all-out attack on those advocating homosexual liberation. The mere mention of homosexuality was enough to incur the wrath of the right.

The social phenomenon of Germany's hatred and intolerance for homosexuals brings me to the subject of my thesis. Given Germany's antigay hostility, it seems peculiar that any writer would publish a story with even remote homoerotic content. But such was the case with Thomas Mann's novella, Death in Venice, written in 1911 and published a year later. Mann's novella emerged in the post-Eulenburg era, a period when the public's recollection of sordid, anti-gay propaganda was still very fresh. Death in Venice was immediately met with staunch resistance. A borage of early attacts on Death in Venice illustrates Germany's preoccupation with objectifying homosexuals. The literary public's reaction to Mann's novella 
was paradigmatic of Germany's enmity towards homosexuals. By looking at the novella's reviews just after its publication, one gains an immediate picture of the climate of public attitude toward homosexuality.

The reception of Death in Venice immediately following its publication can be divided into four groups. In general, acceptance and approval of the novella was dependent on the approval or endorsement of the homoerotic theme. 5 The first group of critiques includes those reviews that appeared in homosexual journals. The treatment of the homoerotic content of Death in Venice - or "sujet", as Böhm writes - is predictably positive. 6 A second group contains those reviews that appeared in nonhomosexual journals, but which nonetheless highly praised the novella on the whole. Of these, two reviewers did not mention homosexuality at all, three simply retold the story, and four provided a decidedly liberal discussion of the "sujet." A liberal discussion in this sense means simply that the reviewers were pleased with the homoerotic content of the novella. The rest explained away the taboo subject as merely symbolic. A third group praised the novella as well, but with reservations. In this third group, four reviewers also pointed to the homoeroticism as being symbolic. Four others found the topic disgusting. Four others ignored the topic altogether, and

5 Karl Werner Böhm, Zwischen Selbstzucht und Verlangen: Thomas Mann und das Stigma Homosexualität (Würzburg: Königshausen \& Neumann, 1991) 18. The statistical breakdown of the reviews for Death in Venice is from the section in Böhm's book that details the early reception history of the novella.

6 Here, "sujer" is the French equivalent of the German "Stoff," and refers to the homoerotic theme of Death in Venice. Böhm's use of the French "sujet" is a tongue-in-cheek way to refer to the homosexual content of Death in Venice. Homosexuality was "the love that dare not speak its name." As such, euphemisms were often employed to talk about it. Here, Böhm's use of tsujet" is clearly sarcastic. 
three can be regarded as liberal in their appraisals. In the last group, the language of condemnation is the strongest. One reviewer disliked the novella, but had no aversion to the topic of homosexuality. Three others combined critique of the style with a brand of criticism reserved specifically for the homoerotic "sujet." The last two reviewers in Böhm's list (Bernd Isemann, Sándor Bródy) launched a fire-and-brimstone attack on the homosexual theme. Their remarks are so incendiary that fellow reviewers saw fit to condemn the vitriolic style of their two reviews. ${ }^{7}$

The language of Isemann's and Brody's reviews best illustrates the contentious nature of the novella's perceived homoerotic feature in an intolerant society. For example, Isemann, wrote:

'Diese Art Leidenschaft des Alters aber, sie nennt sich auf gut Deutsch Geilheit - sie ist widerlich, unnatürlich -, ist in jeder Weise unschicklich [...]. Regt sich auf dieses Unziemliche hin in Aschenbach etwas wie ein Widerschein von Gewissen? O nein, dazu ist er zu erhaben, zu verblödet,' Aschenbach ist ein 'Wrack des Intellektualismus,' er ist eine 'blasierte Figur aus Hohlherzigkeit und Schönheitsdusel,' ein 'vollendetes Ekel' und 'zuchtlos ist [...] an diesem Manne in Wahrheit alles, was nicht Schablone ist. ${ }^{8}$

Here, the reviewer looked for an explanation of why and how Mann could present a main character with such inexcusable sexual inclinations. This

\section{Böhm 18.}

8 As quoted in Gabriele Seitz, Film als Rezeptionsform von Literatur: Zum Problem der Yerfilmung von Thomas Manns Erzählungen "Tonio Kröger." "Wälsungenblut," und "Der Tod in Xenedig"' (Munich: tuduv-Veriagsgesellschaft, 1979) 190-191. 
type of conservative attitude was pervasive, and was part of a growing sense of German nationalism to which Isemann clearly subscribed. 9

Another reviewer, the Hungarian writer and literary critic Sándor Bródy, published a vitriolic attack on Mann and his novella. Even though he was not a German national, Bródy ascribed his own conservative views to the conservative social politics in Germany at that time. He wrote,

\begin{abstract}
Unser deutscher Romanheld erblickt einen hübschen und vornehmen - polnischen Knaben und beginnt sich für ihn zu interessieren. Der Knabe und seine Umgebung reagieren nicht, und unser Held hat keinerlei Aussichten. Seine Sehnsucht ist unglaublich groß, Hoffnung gibt es nicht, und auch an dem seiner Krankheit entsprechenden Mut fehlt es ihm. Armer alter Herr - ich bin kein hartherziger Mensch, aber ich empfinde doch eher Abscheu als Bedauern für dich! Wo soll das enden? Was geschieht mit dir und deinen langsam gezüchteten und plötzlich hervorgebrochenen perversen Gefühlen? [...] Das ist der Tod - der Tod in Venedig. ${ }^{10}$
\end{abstract}

Sándor Bródy decries the novella and its protagonist as degenerate. He was disgusted by the character's homoerotic attraction. But Bródy also reserved criticism for a Germany he saw as having fallen from grace. In his criticism he wrote:

\footnotetext{
9 As quoted in Seitz 190.

10 Antal Mádl und Judith Györi, Thomas Mann und Ungarn: Essays, Dokumente. Bibliographie (Köln: Böhlau Verlag, 1977) 273.
} 
Im Interesse der Deutschen - denn ich achte sie nicht nur, sondern liebe sie auch - bin ich entsetzt über den Erfolg dieses Buches. Was soll das? Sollte das häßliche Thema tatsächlich im neuen Deutschland auf so allgemeines Interesse stoßen?11

He expressed outrage and bewilderment that a county like Germany would entertain such "perversion." Yet another reviewer declined to review the novella at all, because the subject matter was something so far from his personal reality, he felt he wouldn't be able to write about it.

[N]ennen Sie das Liebe? Ich bin weit davon entfernt, Ihnen die Begeisterung für einen Knaben zum Vorwurf zu machen. Mir fehlen die Beziehungen zu dieser Geschmacksrichtung so gänzlich, daß ich mich nicht einmal darürber entrüsten kann. ${ }^{12}$

The reviewer said he did not care about the homoerotic feature. He claimed he could not comment on it - but he did. His argument was double-speak. He wrote: "[...] Thre Art der Begeisterung scheint mir alles andre als Liebe zu sein. Kalte Sinnengier ist sie und nichts mehr [...]. Und dafür sterben Sie auch noch!"13 This type of passive-aggressive statement is replete with homophobic bias.

But not everyone thought of the novella as perverted. In contrast to the right-wing, the growing homosexual emancipation movement gave rise

\footnotetext{
11 Mádl 273.

12 As quoted in Seitz 197-198.

33 As quoted in Seitz 198.
} 
to numerous journals, aimed at homosexuals and their supporters. These journals covered everything from poetry and prose by and for homosexuals, homoerotic photography, political editorials and, of course, literary reviews. These journals contain some - but by no means all - of the positive reviews. In the homosexual journals, the reviewers revel in the introduction of homoerotic literature into the mainstream culture.

The endorsement of homoerotic themes takes an interesting twist in a review by Dr. Kurt Hiller. His critique, which also appeared in a homosexual journal, applauded Mann for even trying to breach the subject matter, but also insisted Mann hadn't gone far enough. 14 The problem Hiller saw was that Death in Venice did not make a strong enough statement advocating a place for homoerotic passion in literature. This reviewer wanted a story about homoerotic love like some of those of history's great writers.

Eine derart wichtige Lebenserscheinung, wie wir sie, aus Erlebnis oder aus Erkenntnis, in der gleichgeschlechtlichen Liebe festzustellen haben, verlangt mit allen ihren Verwicklungen und Tiefen nach dichterischer Gestaltung. ${ }^{15}$

Here we see this reviewer's clear glorification of homoerotic passion. For Thomas Mann and Death in Venice he wrote specifically,

\footnotetext{
14 The journal in question is the lahrgang für sexuelle Zwischenstufen, a rare (and soughtafter) publication.

I5 Kurt Hiller, "Wo bleibt der homoerotische Roman?" Jahrgang für sexuelle Zwischenstufen (1914): 338.
} 
Die ungewohnte Liebe zu einem Knaben, die in einem Alternden seltsam aufspringt, wird da als Verfallssymptom diagnostizert und wird geschildert fast wie die Cholera. ${ }^{16}$

The review laments the notion that Mann has relegated homoerotic passion to the level of physical sickness. Clearly, the reviewer is an advocate of homosexual liberation. But he believes that in Death in Venice his wishes were not quite fulfilled. Nonetheless, the homoerotic feature of the novella, however unfulfilled, is the framework on which be based his review.

Without regard to its endorsement or vilification, Death in Venice's homoerotic theme was clearly the focus for most reviewers. ${ }^{17}$ Thus, the vast spectrum of reviewer opinions about the novella's same-sex notion supported the need for an analysis based on the homoerotic elements. The overwhelming number of reviews mentioning homoeroticism, either positively or negatively, clearly point to a subject matter that merits discussion. And from the small group of critics who completely overlook the subject of homoeroticism, the silence is deafening. A comprehensive grouping of all the text's initial reviews draws a panorama that highlights vitriolic objection to the subject matter on one end, to "liberal" acceptance of the topic on the other. 18 One can use the text's initial reception as a mirror to reflect that element of the novella that is lauded, reviled, or conspicuously circumvented - the homoerotic element. These contradictory reviews

16 Hiller 338-339.

17 As discussed in Böhm.

18 Böhm 17-19. 
reflect the tension inherent in the homoeroticism of Death in Venice. This thesis is an analysis of that homoerotic tension. 


\section{HOMOEROTICISM AND DEATH IN VENICE}

In the late 1970s and early 1980s, previously unpublished portions of Thomas Mann's diaries were released for publication. These excerpts contained passages that removed all previous doubt as to Mann's sexual proclivities, affirming his homosexual inclinations. It had been suspected that Mann was homosexual before this time, but there was no conclusive proof until the release of the now-famous (or infamous) diary entries. ${ }^{19}$ For many students and literary scholars, this information is precious evidence in their research of Mann and his writings. Their view is that Mann's sexuality is an integral part of understanding his literary texts - they view sexuality as a meaningful facet in human existence and artistic production. 20 For these researchers, sexuality is a primal source for literary imagination and creativity. To ignore one's sexual nature is to ignore a significant and determining factor in an artist's being.

In this portion of the thesis, I will analyze the homoeroticism in Death in Venice, including those homoerotic elements associated with Mann's

19 Karl Werner Böhm, Zwischen Selbstzucht und Verlangen: Thomas Mann und das Stigma Homosexualität (Würzburg: Königshausen \& Neumann, 1991) 17-19. Böhm illustrates this widely held belief by using the reception history of Death in Venice - how the critics focused heavily on the subjects of homosexuality and pederasty. Some critics attacked the author as disgusting and degenerate. There was wide speculation as to why a prominent author like Mann would have written about such a topic.

20 Stuart Kellogg, ed., Literary Visions of Homosexuality (New York: Haworth, 1983) 1. Much of the discussion in my thesis that deals with homosexuality and its place in literary criticism comes from the anthology edited by Kellogg - the last of a six-part series of Research on Homosexuality. 
repressed homosexuality. The purpose of this analysis is not to emphasize the nature of Thomas Mann's sexual proclivities. Instead, its intent is to organize and highlight the homoerotic elements in the novella. However, in order to investigate the homoerotic elements of Death in Venice, one must investigate the motivating force behind writing a story dealing with homosexuality. ${ }^{21}$ There is now a great body of recently published evidence that clarifies the long-suspected, private side of Mann's specifically homosexual inclinations. 22 Incorporating these biographical elements into an analysis of the text highlights the motivation for and the power behind the need to discuss the psychological, sociological, and physical nature of homosexuality.

Given society's pervasive disapproval of homosexuality, especially at the time Mann wrote Death in Venice, it might seem astounding that a writer of Mann's stature would have dared deal with the topic in any way. ${ }^{23}$ But there are many reasons why a writer might do just that. ${ }^{24}$ One essential reason is that literature is a part of life itself - it is part of a larger continuum of human expression, of which sexuality is a part. Literature is a snapshot of how humanity views itself, a moment in human nature. Part of

\section{Kellogg 3.}

22 Böhm 67-68. Biographical elements of Mann, especially as these relate to his homosexual inclinations, are also found in several new works, including those by Baumgart, Feuerlicht, Nussbaum and Reich-Ranicki. Many detailed diary entries will come from Böhm's exhaustive analysis on Mann and the societal stigma of homosexuality.

23 James D. Steakley, The Homosexual Emancipation Movement in Germany (Salem, New Hampshire: Ayer, 1975) 1-61. Much of the historical information about homosexuality, including the Wilhelmine era, comes from Steakley's rich account (chapters one and two) of the homosexual emanicipation movement in Germany. The book details societal opposition to the movement, as well.

24 Kellogg 4-12. 
human nature is human sexuality, and one "aspect of [that] is homosexuality, defined here as sexual appreciation of, desire for, or sexual behavior with a member of the same sex." 25 Sexual appreciation of a member of the same sex as a fundamental theme in Death in Venice is the basis of this thesis. Mann insisted he never would have written the story had it not been for his homoerotic "Gefühlsabenteuer" - especially with one particular young man in Venice. 26

During a trip to Venice - specifically the Lido - in 1911, Mann encountered a boy whose beauty captivated him. Mann's wife, who was travelling with him, recalled that he was "immediately fascinated" with the boy and followed him everywhere.27 And although he never even learned his name, Mann's fascination with the boy was inspirational enough for the creation of Death in Venice. ${ }^{28}$ But his obsession with the attractive lad was an erotic fantasy that could only be pursued in the confines of a carefully drawn, yet still very controversial story. Mann was forced by societal convention to process the experience with the young beauty in the least explicit way possible. The struggle between his homosexual tendencies and the repression of them in an intolerant society demanded the utmost scrutiny in crafting a story with a homoerotic feature. As the reviews implied, Death in Venice was a potentially volatile product in Mann's attempt to bring his closely-guarded homoeroticism into his work. Mann

\footnotetext{
25 Kellogg 1.

26 As quoted in Hans Rudolf Vaget, Thomas Mann: Kommentar zu sämtlichen Erzählungen (Munich: Winkler Verlag, 1984) 178-179.

27 Feuerlicht 91.

28 Vaget 178-179.
} 
was, in fact, relieved that the novella received what positive acclaim it did. He had expected much worse. While he was writing Death in Venice, Mann repeatedly referred to the novella as an impossible task. For Mann, the impossible part of the task was in publishing a story with homoerotic content. 29

Gustave von Aschenbach, the protagonist in the tale, is a representation of Mann and his homoerotic experience. ${ }^{30}$ Aschenbach's journey to Brioni and to Venice, including his stay at the Lido, is an inspiration from Mann's personal travel $\log .{ }^{31}$ Mann and his creation Aschenbach both experienced a fervant infatuation with a very young man in Venice. But Aschenbach embodies more of Mann than just one experience in Venice, or his affinity for attractive young men. The parallels between Aschenbach and Mann are numerous. One can begin by comparing their identical professional lives. Not only are they both writers; they are the same type of writer. Mann, like Aschenbach, was a "Genie des Durchhaltens und der Genauigkeit." 32 He was obsessed with maintaining order in his daily life. Mann's routine was regimented. He forced himself to schedule copious amounts of time reserved just for his writing. But Mann's preference for order was based in his inability to cope with chaos. The public image of the diligent writer had another, contrary and equally powerful side.

29 Vaget 181. Here, Vaget mentions Mann's dilemma - referred to as the "impossible" task of writing such a contentious story.

30 Jean Jofen, "A Freudian Commentary on Thomas Mann's Death in Venice," Iournal of Evolutionary Psychology (August 1985): 238. This citation is merely one of many such statments paralleling Mann and Aschenbach.

31 Vaget 172.

32 Reinhard Baumgart, Glücksgeist und Jammerseele: Über Leben und Schreiben, Vernunft und Literatur. (Munich: Carl Hanser Verlag, 1986) 41. 
And his veneer of self-control concealed a completely different person on the inside. ${ }^{33}$ As Heinrich Mann once pointed out, Thomas was a "Genie" only during business hours. ${ }^{34}$ This genius image the public had of Mann emanated from his professional image, which was the staid, pragmatic ironist. During the off-hours, the private Mann was quite different.

These contrasting personalities are exactly those of Aschenbach, who can thus be seen to represent the two conflicting sides of Mann - the diligent and dignified writer of world renown, and the lonely and sexuallyfrustrated recluse. ${ }^{35}$ As a socialite, Mann was constantly surrounded by people yet felt he was always utterly alone. ${ }^{36}$ Mann's closely-guarded homosexuality accentuated his isolation from those around him. The division is one in which Mann and, later, Aschenbach, who represents and reflects Mann's dilemma, tries to channel homoerotic passion into the realm of intellectual prowess. The tension between these two desires - the wish to remain a highly-respected writer and the need to give in to homoerotic passions - is the foundation for both Thomas Mann's and Gustave von Aschenbach's quandary. Their shared predicament was that "[sie gierten] nach Lob, [sie waren] süchtig nach Anerkennung. ${ }^{37}$ But they were also

33 Baumgart's analysis of the diaries of Mann creates an image where Mann's only escape was the diaries. Mann used them as a way to maintain his sanity in the face of overwhelming pressure from the literary public and his inner desire to live freely.

34 Baumgart 50.

35 Mann's sexual frustration as it pertains to the novella will be discussed in more detail further on in the thesis. See the analyses in Feuerlicht, Reich-Ranicki, or Böhm for more Information.

66 Marcel Reich-Ranicki, Thomas Mann und die Seinen. (Stuttgart: Deutsche Verlagsinstalt, 1988) 33.

1) Reich-Ranicki 55. 
closeted homosexuals. Both men "[...] suffered under latent homoerotic tendencies that nurtured and blessed their writings, but cursed their lives."38

Throughout the novella Aschenbach's character assumes and projects this conflicting dualism in various ways. His family history is one example of this dualism. Aschenbach's geneaology provides a clear metaphor for his inner turmoil. The introduction into his past takes place after a narrative rupture only six pages into the story. This rupture is a physical space in the text, a pause breaking the flow of the story to introduce the reader to Aschenbach's family history and his conservative past. Up to this break, the novella is written in the present tense. Aschenbach is shown fleeing his work environment to go for a walk. He is frustrated, unable to concentrate on his work. While on his walk he experiences strange apparitions and becomes confused and absent-minded. In this introductory section, Mann portrays him as an eccentric, neurotic man whose disoriented motives are ambiguous and bothersome. The background information that follows the narrative pause begins to shed light on the enigmatic Aschenbach. His biographical sketch reads like a psychological case history or resumé. One reads here about the strict self-discipline that Aschenbach inherited from his father's side. His paternal forebears were “[...] Männer, die im Dienste des Königs, des Staates ihr straffes, anständig karges Leben geführt hatten."39 These sober men were the examples Aschenbach had to follow. These stoic men were his role models. They were austere and unyielding examples of 
how to live one's life. His mother, on the other hand, the daughter of a bohemian conductor, represents the other half of his persona - the lyrical and passionate individual. From her he inherited artistic qualities and a strong passion for life. Thus, Aschenbach's genealogy physically illustrates the innate struggle of the two opposing features of his character. His father exemplifies strictness and duty. The maternal side exerts itself in his creativity and license. On the one hand Aschenbach is a meticulous and industrious person. He has attained world acclaim for his writing. Everyone has pushed him to be great. The change from Aschenbach to von Aschenbach intimates the literary prominence he has gained by his fiftieth birthday. The name change reflects the high livel of social legitimacy he has reached. Another measure of his public acceptance is the adoption of his texts for instructional use in schools. But Aschenbach, as character of literary greatness, possesses personality traits which resemble a tightly closed fist.
Als er um sein fünfunddreißigstes Jahr in Wien erkrankte, äußerte ein feiner Beobachter über ihn in Gesellschaft: 'Sehen Sie, Aschenbach hat von jeher nur so gelebt' - und der Sprecher schloß die Finger seiner Linken fest zur Faust -; 'niemals so' - und er ließ die geöffnete Hand bequem von der Lehne des Sessels hängen (13).

The fist metaphor represents his bridled and austere personality. Today we would quickly diagnose Aschenbach, only slightly erroneously, as having an anal personality. Aschenbach's anal-retentive personality further asserts itself in his personal motto, "Durchhalten." 40 This scatological reference 
illustrates the Freudian concept of an anal-retentive person. 41 The image produced is of a man who "holds it in" and delays gratification. This is how Aschenbach lives and works. He tries to repress and control natural functions and desires.

Aschenbach shares a strikingly similar family history with that of Mann. Mann was also the product of two distinct family types. His father was a forthright and conservative patrician from a long line of the same. His mother was part Portuguese, and given to fits of artistry and passion. Her image of foreignness and exotic impulse contrasts sharply with the staid example of the father. Physically, Mann favored his mother, but his outward rigidity was strictly paternal. This geneaological dualism is the same one represented in Aschenbach. And like his protagonist, Mann had to combat the inner struggle "[...] between the rigorous officialdom of his father and the obscure impulses of the mother."42 This struggle is the basis for Mann's obsession with self-control versus passion. He opted for the conservative side and concealed his passion. Mann felt he needed to maintain his public image at all cost. He reveled in his fame and, like Aschenbach, always felt he had to be "gütig und bedeutend." 43 The scatological "Durchhalten" motto clearly holds for Mann, as well. In his diaries he frequently details his intestinal state by writing that he was always either constipated, or he was plagued with diarrhea. His physical state was either completely wrenched or uncontrollably yielding. Some diary entries regarding his physical state read:

41 James Strachey, Civilization and its Discontents. (New York: W. W. Norton \& Co., 1961) 51-52.

42 Jofen 240-241.

43 Reich-Ranicki 12-13. 
"Meine Constipation ist außerordentlich" and "hartnäckige Verstockung des Unterleibs." 44 These contrasting images of chronic stoppage (the constipation) and laxity (the diarrhea) are physical manifestations of similar psychological states. The physical malaise is a metaphor for the tormented workings of his psyche.

If Mann was given to intestinal problems, he was equally plagued with psychological traumas, which often appeared in the form of illness or frequent nervous breakdowns. 45 His physical and mental states were greatly affected by the role he had to play in life - a role imposed from within as well as by society. Aschenbach's situation illustrates this suffering. Aschenbach resents that he is "zu beschäftigt mit den Aufgaben, welche sein Ich und die europäische Seele ihm stellten, $z u$ belastet von der Verpflichtung zur Produktion" (10). In this statement the inner and external expectations of the self are clear. Aschenbach is working in a society that demands too much of him. He also laments that his "Ich" - his own self has internalized the rigorous demands of society. This is symptomatic of Aschenbach's dilemma; and the same held true for Mann.

Aschenbach's fame is a result of his writings, and his writings further illustrate the connections between creator and protagonist. Mann's worksin-progess at the time he began Death in Venice became his protagonist's famed works, and these works themselves reveal the sexual struggle shared by both writer and protagonist. 46 Aschenbach's earlier book, Maia, refers to

\footnotetext{
4 As quoted in Reich-Ranicki 37.

Reich-Ranicki 33-37.

Vaget 171.
} 
the Veil of Maya that is "supposed to hide relentless striving of the one primordial Will, and allows us to believe in our illusory individuation."47 We are supposed to believe that Aschenbach is a writer, an artist with incredible gifts, but also one who practices seemingly unyielding self-control. But it is equally clear that he is repressing something beneath his societally acceptable façade. In reflecting on his work, Aschenbach says he loves it, but not the
“[...] sich täglich erneuernden Kampf zwischen seinem zähen und stolzen, so oft erprobten Willen und dieser wachsenden Müdigkeit, von der niemand wissen und die das Produkt auf keine Weise, durch kein Anzeichen des Versagens und der Laßheit verraten durfte" (11).

Aschenbach's urgent sense of secrecy and paranoia about his homoerotic longings is revealed here. He fears his nucleus of inspriration could be revealed, and he will go to great lengths to guarantee secrecy. This is Mann's own modus operandi in concealing his homosexuality. Even in his diaries, Mann believed that there was something so "Umheimliches $\mathrm{zu}$ verbergen, daß er auch zu sich selbst nur in Andeutungen darüber redet."48 Aschenbach clearly serves as mouthpiece for Mann's own sexual paranoia. Mann assigns another of his personal projects - Die Elenden - to his protagonist. This title also reflects Mann's concealed, miserable state of mind. The diary revelations of his pathetic emotional situation contrast sharply with the successful public figure that presents him as a sovereign

\footnotetext{
47 Richard White, "Love, Beauty, and Death in Venice," Philosophy and Literature 14.1 April 1990) 62.

8 Baumgart 46.
} 
man. Also, that Aschenbach has written an epic on the life of Frederick the Great is no coincidence.

It is never accidental that a writer chooses to write about a particular subject. We know that Frederick the Great was a homosexual, and Mann admits that Frederick's life was a manifestation of great power working under high pressure. 49

Taken as a threesome, Frederick the Great, Aschenbach and Mann create strong symbols of intense homoerotic desire and sublimation of the same. In Mann's case, he was able to flee into his writing to process his true feelings and desires. His work often functioned as a type of ersatz social relationship.50 As someone who could not fuse personal relationships, Mann's only outlet was his writing. He once wrote, "Arbeit ist schwer [...]. Aber nicht arbeiten - das ist die Hölle."51 His avoidance of the type of intimacy he desired is clear in the preceding quote in which he expresses gratitude for his work. For without his work, he would have to face the harsh reality of the constant, nagging desires he tried so desperately to repress. 52 Aschenbach manifests these same characteristics as Mann - an artist who works under the greatest possible amount of self-discipline. But

49 Jofen 241.

50 Böhm 128-130.

51 As quoted in Böhm 128.

52 Baumgart 49-50. Baumgart makes the comparison between the humorist, apparent in his works, and the afflicted artist, apparent in his diaries. His diaries portray a lonely, dejected person devoid of humor. As for the humoristic societal demands put upon Mann by the literary public, Baumgart writes "Die Privatperson Thomas Mann, konfrontiert mit der Unordnung des täglich Vorfallenden, war zu diesen Leistungen der Heiterkeit weder willig noch fähig." 
an artist who also sublimates his passion - one who rechannels his erotic urges in order to maintain a societally acceptable façade.

Aschenbach's literary achievements were products of pure spite. In reflecting on his own literary experience, he writes:

\begin{abstract}
“[...]daß beinahe alles Große, was dastehe, als ein Trotzdem dastehe, trotz Kummer und Qual, Armut, Verlassenheit, Körperschwäche, Laster, Leidenschaft und tausend Hemmnissen zustande gekommen sei" (15).
\end{abstract}

Great personal sacrifices are the price of his success. The image produced is one of denial and sublimation - where a man pushes himself to work hours on end, to deny himself relaxation and pleasure. The repressed nature of Aschenbach is a reflection and representation of Mann's repressed nature - of Mann's inability to live openly. As I have pointed out, Mann's public side was very different from his private one, and his only escape was into his diaries. 53 Perhaps the most stirring revelations in the diaries are those dealing with his homosexuality, the nature of which he felt he could not publicize during his lifetime. In fact he stipulated that his diaries were not to be opened until twenty years after his death. This was meant in part to protect those individuals implicated in his diaries. His repression and selfdenial were thus safely unveiled in the form of diary entries - a medium that could guarantee secrecy.

53 Reich-Ranicki 34. Reich-Ranicki writes that Mann's diaries were a "Schlupfwinkel" for him. The diaries were where Mann could escape the pressures of his fake public existence where he could never lose control or step out of his role. "Es war sein Asyl und sein Rettungsring." 
The title of Marcel Reich published portions of Mann's diaries reflects the infamy of those entries. It is entitled, "Die ungeschminkte Wahtileit. Whe Mann's homoerotic passion is bridled in the public spltere, it is experienced as unfettered delirium in his diaries. Reich-Ranicki presents that passion plainly, without pretense or euphemisms.

Immer wieder erfaßt der Blick dieses korrekten Herrn, mit Mitte Vierzig und noch mit Mitte Sechzig, schöne Jünglings- und Knabenkörper, einen Gärtnerburschen in München oder einen schwarzen Ballspieler am Strand von Los Angeles. 54

Mann describes these men as being "wonderfully built," "enrapturing;" personally, some of them did "give him great trouble." 55 And his attraction to boys, men, and the male form in general was always under a spell that he can only describe as total "Ergriffenheit." 56 His infatuations make his seem possessed. Although Thomas Mann did experience several meaningful homosexual relationships in his lifetime, most of his homoerotic desires were left unrealized. He forced himself to repress them and used his writing as a form of erotic experimentation instead. 57 This sexual contradiction that

\footnotetext{
54 Baumgart 47.

55 Ignace Feuerlicht, "Thomas Mann and Homoeroticism," Germanic Review LVII, 3 (Summer 1982): 91. In regards to his wife, Katia, their sexual relationship was non-existent, especially after 1921 where he confesses to her that he has "wishes that go to the other side." He blames his impotence with her on his "unual confusion and unreliability of his sex life."

56 Baumgart 47.

57 Böhm 68.
} 
Mann had to endure his entire life was an internalized standard of sexual repression. 58

It is not the many details of Mann's lifelong homosexual experiences that are important in the present thesis. What is important in analyzing the homoeroticism extent in the novella is the tension created between the burden of living a forced and false existence publicly, and having to place contraints on his homoerotic inclinations. Mann manifested two very different personae - one public and one private. Living this lie, as Mann did, gave birth to such stories as Death in Venice. 59 Indeed, his homoerotic tendencies were the driving force of his works, which manifest a constant mutation of the conflict of order versus chaos. 60 This is his "erotic irony." 61

In keeping with the connection of life experience and literary production, Mann infuses Aschenbach with further similarities. In the novella, Aschenbach's renown is a carefully-crafted product of his own doing. We read that

"[b]einahe noch Gymnasiast, besaß er einen Namen. Zehn Jahre später hatte er gelernt, von seinem Schreibtische aus zu repräsentieren, seinen Ruhm zu verwalten[...]" (13).

58 Reich-Ranicki 49. Once, Mann publicly defended Graf August von Platen's sexuality as being just another type of sexuality. Mann was trying to help assimilate homosexuality into the realm of publicly-accepted heterosexuality. But Reich-Ranicki points out that an unrealized same-sex relationship (and Mann kept most of his homoerotic/voyeuristic experiences to himself) is hardly like any other love.

59 Feuerlicht 90-91. See also Böhm 130-132.

60 Baumgart 48.

61 Thomas Mann, Gesammelte Werke in dreizehn Bänden, vol. 11 (Frankfurt am Main: S. Fischer 1961-1974) 110. 
Aschenbach took control of his own professional security by creating his own public image. He had to. While many writers receive acclaim posthumously, Aschenbach's fame began early in his lifetime. So, it was imperative that he produce his own public image, for fear someone would reveal his private, homosexual side, or some closely guarded incident associated with his sexuality. Mann worked an identical scheme. ${ }^{62} \mathrm{He}$ attained a high level of literary success early in his life, which enabled him to contrive and maintain his own public image. For fear that someone could produce damaging information about him and/or the autobiographical elements in his works, Mann made sure he always created his own secondary literature. 63

From Mann's diaries, however, we now know that the visible composure was merely a front. He was not successful, by any means, in completely repressing his homoerotic desires. The diaries provide conclusive proof of Mann's inner turmoil and his frequent breakdowns. 64 Aschenbach, too, possesses a similar veneer. His composure is seemingly guaranteed by the unrelenting and exacting expectations, exerted from within and without. However, this is temporary - it is a façade like Mann's. Aschenbach spends long, arduous hours writing. He produces

62 Reich-Ranicki 31. Reich-Ranicki writes that "das Bild, das sich die Menschen von Thomas Mann gemacht hatten, entsprach in hohem Maße seinen Wünschen."

63 Baumgart 38. Baumgart makes the comparison between Mann's works and his diaries. The diaries, he notes, were not produced with the usual secondary literature. The homosexual image of Mann in his own diaries is unmistakably clear. His works, however, would be subject to varying literary criticisms. To thwart any major controversies, he produced his own critical literature and marketed it as the definitive approach to his writings.

64 Baumgart 41. Baumgart contrasts the public image of Mann to one where, in the diaries, Genuß gibt es fast nie, Behagen manchmal, aber das scheint dann immer nur ein kurzes, orsichtiges, gefährdetes Atemholen vor dem nächsten Überfall der Welt." 
feverishly for his literary public, and when he emerges from the confines of his workplace to seek rejuvenation, it is because he is distracted and tired. His ability to fight his most primal urges wanes. Unable to overcome the fatigue, he goes out to seek diversion.

In contemporary psychological terminology one would diagnose Gustave von Aschenbach's dilemma as chronic denial. In Freudian terms it is sublimation. 65 To take it a step further, his dilemma is tragedy in the classic sense. In other words, it is the place in the soul where Nietzsche's idea of the dionysian and apollonian dualism battle for control over the individual.66 The novella's theme of Aschenbach's homosexual repression resulting from his accomodation of society's sexual morals takes form in a dialectic struggle of Dionysus versus Apollo. Death in Venice portrays the struggle of the dionysian and the apollonian through the psyche of the tormented protagonist. 67 The sudden apparitions of Dionysus reflect Aschenbach's moods throughout the novella. The god of revelry and raw, erotic power, makes his first appearance to Ashenbach in the form of a stranger with a straw hat and an Adam's apple that is "stark und nackt" (8). Here, the tribes of Dionysus begin to exhibit their trademark eroticism. Their powerful sexual appeal, appearing interchangeably as female or male, mystifies Aschenbach. When the dionysian stranger appears, Aschenbach is

\section{Strachey 23.}

66 Walter Kaufmann, trans., The Birth of Tragedy and the Case of Wagner (New York: Vantage, 1967). See also Reinhard Baumgart, "Thomas Mann als Erotischer Schriftsteller," Forum: Homosexualität und Literatur (April 1988) 5-6. In this article, Baumgart analyzes the recurring theme of Dionysus as Leitmotif in Mann's writings.

67. Vaget 180. Vaget restates the claim that Die Geburt der Tragödie aus dem Geiste der Musik, with its Dionysian and Apollonian elements, was in fact a "Vorbild" for Der Tod in Venedig. 
captivated by the man and cannot look away. He is embarrassed that someone would glare at him so unabashedly. A sudden state of absentmindedness and day-dreaming in Aschenbach accompanies this and each subsequent visit by a representative of Dionysus. The appearance of the dionysian symbol impedes Aschenbach's normal thought process. A momentary obsession - a lapse of self-control in thought and action. Here we get our first glimpse of the dionysian forces inside of Aschenbach, battling with his normally self-controlled and repressed psyche - in his case the repression surrounds his latent homoerotic desires. The appearance of the first dionysian stranger precedes, and we assume causes, Aschenbach's homoerotic daydream in which he envisions "haarige Palmenschäfte" and ferocious, crouching tigers (10). This dionysian daydream represents a subconscious escape, an initial gravitation toward his homoerotic desires. The hairy palmtree reference creates a stark phallic symbol and the tiger portrays a creature given to unbridled, hedonistic passion. Further, the tiger is the draught animal of Dionysus' chariot. These items are clearly metaphors for sexual and primal urges. These are the homoerotic urges that Aschenbach has suppressed. Thus, the unveiling and dialectical struggle of the sexual psyche begins very early in the story.

After the erotic daydream, Aschenbach ponders another type of psychological escape, namely a trip. The frustration he experiences from not being able to write, and the general sexual malaise resulting from his repression force him to escape from his normal surroundings. His plans for a physical journey to match his psychological one create graphic symbols of the exotic, erotic, and highly-charged daydream he has just experienced. 
Mann travelled quite frequently, as well. And his travels were also a form of escape for him. Aschenbach uses travel as an escape, as well. He wants to get away, but not to a place as forbidding as his dream - "nicht gerade bis zu den Tigern" (12). Here, Aschenbach exhibits his seemingly stalwart resistance to passion. He agrees he has to get away, but is consciously trying the fix the limits of his journey. The stated compromise of not wanting to go all the way to the tigers is a weighed decision. His sexual frustration is a dionysianinduced, subconscious motivational factor for wanting to escape; the determination to remain this side of the tigers is the conscious apollonian exerting itself. This compromise indicates that there is a great deal of selfdenial and personal restraint left in him. However, the initial vascillation represents the beginning of the battle between his subconscious dionysian desires and his acquired taste for the apollonian. Aschenbach has already been touched by the dionysian tribes - he's experienced the homoerotic visions. Before this moment, he had been content to know as much of the earth's surface as possible without going too far. But no more. Aschenbach's desire to escape his metaphysical incarceration drives him harder to go beyond his previous personal boundaries. The impatience and increasing discontent with his personal boundaries signal a greater journey for Aschenbach than he has yet experienced. He wants to be in a place where he can be "bezugslos." 68 He experiences a need to get away - a "Fluchtdrang" (11). What he possesses is a "Begierde nach Befreiung, Entbürdung und Vergessen" (11). He can no longer sublimate his homoerotic desires and the

of Georges Bridges, "The Problem of Pederastic Love in Thomas Mann's 'Death in Venice'," electa: Journal of the Pacific Northwest Council on Foreign Languages 7 (1986) 40. 
freedom offered by strange surroundings would allow him to let down his guard.

Aschenbach's journey to and in Venice procedes after another narrative rupture separates it from his family history. Again, the text is physically set apart to force the reader to break with the flow. The daydream, followed by the historical information on Aschenbach, has now made the nature of his sexual repression clear. After the interruption of the background information on Aschenbach, the tale begins anew. The reader is thus prepared to better understand the symbolism of the voyage. The journey to Venice is fraught with dionysian symbolism. Aschenbach has insisted on being near the sea instead of in his perennial mountain retreat where he knows he would feel closed up. The sea is a common trope as a female identity. The androgynous and ambiguous nature of Dionysus has given Aschenbach license to entertain new plans and ideas. This passage indicates Aschenbach is breaking out, and that his dionysian side is taking on greater influence in his decision-making. He becomes more willing to try new things. Characters and symbols in this part of the novella are mysterious in their dionysian character. The ticket salesman aboard the ferry has a beard like a goat. The goat is a symbol associated with Dionysus, creating another intimation of Aschenbach's metamorphosis. The ticket saleman's behavior is peculiar and furtive. His statements to Aschenbach about Venice contain special meaning for the story. 


\begin{abstract}
Ah, Venedig! Eine herrliche Stadt! Eine Stadt von unwiderstehlicher Anziehungskraft für den Gebildeten, ihrer Geschichte sowohl wie ihrer gegenwärtigen Reize wegen (20)!
\end{abstract}

The kind of Venice being lauded here permits a man of stature, like Aschenbach, to revel in Venice's traditional culture. But is also provides a place to enjoy the young charms of the flesh. The previous quote exemplifies Aschenbach's psychological tug-of-war. Aschenbach can openly delight in going to Venice as a cultured man, but he can also secretly revel in her present charm. His approach into Venice holds promise for adventure and sexual intrigue.

As Aschenbach arrives in Venice, a warm east wind, a scirocco, begins to blow. The scirocco is the continuation of many dionysian apparitions to confront the traveller. Dionysus blew in from the eastern lands to the Hellenic world. Hence, the scirocco is another manifestation of a dionysian invasion - Venice being the symbolic point of mediation between the reason of the west and the emotion of the east. Everything Aschenbach experiences is peculiar and a bit out-of-the-ordinary. His encounters are embued with mysterious and perplexing sensations. The gondolier who eventually transports him from the ferry to the hotel is also a representative of the tribes of Dionysus, and has the familiar snub nose. The snub nose comes from Socrates' discussion of snub-noses, a traditional symbol of 
satyrs. 69 The route the gondolier takes to the Lido frightens and alarms Aschenbach's sense of normalcy. He insists in his own mind that he is being given the run-around, or worse, that he may be rowed off to some forsaken canal and murdered.

Die Vorstellung, einem Verbrecher in die Hände gefallen zu sein, streifte träumerisch Aschenbach's Sinne, unvermögend seine Gedanken zu tätiger Abwehr aufzurufen (27).

He is petrified, but even more intrigued. And he is helpless against the thought control of the gondolier - or, rather, Dionysus' representative. The mystery of the gondolier remains a mystery to Aschenbach, having been delivered to his destination safely, as he runs back to pay the boatman, only to find him gone. Clearly, the gondolier is a dionysian figure, literally transporting him to his new life experience. Reference is also made to the gondolier's teeth. The pervasive leitmotif of teeth is a metaphor for that which is primal and essential. The mouth seeks out pleasure almost immediately after birth. The mouth is the first source of a human's unmitigated demand for corporeal satisfaction - the elementary focal point for pleasure and self-satisfaction and, hence, a metaphor for the dionysian.

Perhaps the most powerful intimation of dionysian influence over Aschenbach is the drunken fop who appears to him while he is still on the ferry. The contemplative journey on the ferry is suddenly interrupted by the

69 Tom Hayes and Lee Quinby, "The Aporia of Bourgeois Art: Desire in Thomas Mann's 'Death in Venice'," Criticism: A Ouarterly for Literature and the Arts 31.2 Spring 1989: 167. See also Phaedrus. 
antics of an aged, inebriated, drag-queen-like figure and his youthful (allmale) entourage. Aschenbach is puzzled by the mixed group. He admires the youths and wonders why they would tolerate the company of such a fellow. The old fop has used cosmetics to appear younger. And he is overtly effeminate, as Dionysus can be. The text also mentions that he is drunk on wine (Asti) - perhaps the most well-known of the dionysian symbols. And here again Aschenbach falls into a state of bewilderment that he cannot control. He says of the fop, he
[...] leckte auf abscheulich zweideutige Art mit der Zungenspitze die Mundwinkel. Aschenbach sah ihm mit finsteren Brauen $\mathrm{zu}$, und wiederum kam ein Gehühl von Benommenheit ihn an, als zeige die Welt eine leichte, doch nicht zu hemmende Neigung, sich ins Sonderbare und Fratzenhafte zu entstellen [...] (24).

At this point in Aschenbach's journey, the ability to thwart dionysian desires wanes even more. He feels numb and helpless against his sexual desires. The symbols for the dionysian are everywhere. On the one hand, the lewd fop repulses Aschenbach, yet Aschenbach keeps looking at him make the repeated gestures with his tongue. The dionysian in him exhibits obsession with the lewd behavior, but he puts on airs to appear repelled - the societally acceptable apollonian. The fop introduces what is clearly the first intimation of the homoerotic adventure awaiting Aschenbach in Venice. Before disembarking form the ferry, the fop slurs the lines, "Unsere Komplimente," "unsere Komplimente dem Liebchen, dem allerliebsten, dem schönsten Liebchen" (25). This statement indicates that Aschenbach, who is travelling alone, will not be alone for long - that he will encounter a 
lovely beauty, the most beautiful, in fact. The dionysian fop, while relishing the images of youthful beauty, instructs Aschenbach to send the young beauty his best regards. Repulsed, but also beguiled, Aschenbach manages to slip past the drunken fop and continue his journey into Venice.

Mann, himself, harbored a similar love/hate relationship with such fop-like figures. He saw certain elements of himself in these characters. 70 On one hand, there is the promise of sexual intrigue awaiting such characters; but there is also the fear that such desire is wasted on an old man who makes pathetic, cosmetic attempts to relive youthful passion. At the time Mann wrote Death in Venice, he was 35, and had already had homosexual lovers. One can imagine that Mann longed for youthful passion, but was also witnessing the result of his own aging. In Death in Venice the sexual intrigue and the opportunity to resuscitate youthful passion is centered on Aschenbach's object of desire - the ravishing young Tadzio. During Mann's trip to Venice in 1911, the boy, whose real name was only later determined to be Wladyslav Baron Moes, became the object of Mann's homoerotic desire, and his inspiration for Death in Venice. ${ }^{71}$

That Mann would direct his homoerotic desires at an attractive 14-year old is not surprising. Mann's very first homoerotic experience was when he was that age, and with a classmate of nearly the same age - the 13-year old Armin Martens. The young Martens had blonde hair and blue eyes and, accoring to Mann, the experience was "joyful-painful."72 Even though the

\footnotetext{
70 Feuerlicht 90.

71 Vaget 173.

72 As quoted in Feuerlicht 89.
} 
young Mann's affectionate advances were unrequited, the experience with his classmate would leave a lasting impression. Mann's later fixation on youths of this age - and those with blonde hair and blue eyes - is based on his early amorous longings for his classmate. Armin Martens was his first love. This age preference exhibited by Mann in later years represents a kind of "erotisches Urerlebnis" that colors his sexual proclivities for the rest of his life.73 In fact, twenty years later, while in Venice again, Mann noticed two 14-year olds whose proportions "interested" him.74 Essentially, Mann's experience with Wladyslav (Tadzio) in Venice was symptomatic of his preexisting predilection for young men and boys of this age. It was not his first homoerotic experience with an adolescent and would certainly not be his last.

If Armin Martens was Mann's original standard for Tadzio, Paul Ehrenberg presented nearly all the material for the inner conflict. ${ }^{75}$ In 1900 , Mann, who was 25, met and fell in love with Ehrenberg who was one year younger. Despite closer intellectual proximity than in previous liaisons, the relationship was not an easy one. ${ }^{76}$ It was tumultuous - fraught with jealousies, bitter fights and extreme erotic passion. Before meeting Ehrenberg, Mann felt completely isolated and depressed in his (partially) pseudo role as great literary figure. He was nearly suicidal. But the love affair with Ehrenberg released Mann from his "erotic isolation."77 It gave

73 This term is created by Feuerlicht 91.

74 Peter de Mendelssohn, ed. Tagebücher, 1933-1934: Thomas Mann (Frankfurt a. M.: Fischer 1977) 482.

75 Vaget 178.

76 Mann 11: 107.

77 Feuerlicht 90. 
him some self-confidence. But it also presented a great of deal of extreme emotional trauma for Mann. For even in his homosexual relationship with Ehrenberg, the traces of Mann's intellect/art versus physical/life dichotomy are evident. Mann was extremely uneasy about his homoerotic longings. The love he felt for Ehrenberg was intense. In comparing Ehrenberg with a lover of many years later, Mann wrote that the passion with Ehrenberg was based in the:

“[...] jugendliche Intensität des Gefühls, das Himmelhochjauchzende und tief Erschütterte jener zentralen Herzenserfahrung."78

But Mann also regarded Ehrenberg as being intellectually inferior, a character of life and not of art. Here, Mann's made attempts to force a preference for artistic and intellectual pursuits over physical and earth-bound delights. This attitude was part of his homosexual denial, a defense mechanism to subdue his homoerotic desires. Mann was greatful for the relationship with Paul Ehrenberg, because it brought him somewhat out of his shell, but he also resented him and was critical of Ehrenberg's out-going and flirtatious nature. This antinomy of emotion is further indicative of the inner struggle in Mann, himself. Also, Mann was a passive partner in the relationship with Ehrenberg. ${ }^{79}$ This type of sexual role confounds the issue. As the passive partner in a homosexual relationship, Mann was forced to witness

\section{As quoted in Reich-Ranicki 48.}

79 Author Note: I say "a passive partner" instead of "the passive partner" here to debunk the myth that there is always a clear, or necessary, distinction between partners in homosexual relationships. The textual information is from Feuerlicht 89. 
his own submission in homosexual love. It would have been easier to downplay or hide extreme interest and pleasure in homosexuality if he had been the active partner in intercourse. But such was not the case. He submitted to Ehrenberg. If western society is intolerant of homosexuality, it is especially so in its disdain for the passive (read: weak) partner. Mann's desire to live and love freely was thwarted by his own intense, internalized homophobia. Mann felt he had to temper Ehrenberg's irresistable charm with criticism - a way to convince himself that his lover was not worth loving so he would not have to deal with the consequences. Mann also made mention of always having to "despise anybody who loves him." 80 This was Mann's defense mechanism for keeping his homosexuality in check.

To a great extent these emotional contradictions - jealousy and conflict, yet passion and greatfulness - are the same feelings Mann loans to Aschenbach. The dichotomy of homoerotic passion and fear of exposure takes form in Death in Venice with Aschenbach's anxiety-ridden encounter with the young, male tourist. Death in Venice is representative of Mann's "Liebes- [und] Passionsgeschichten," this time with "von Aschenbach und dem mit seiner Schönheit zum Tode verführenden Knaben Tadzio."81 When Aschenbach first sees Tadzio, he is stunned by the boy's beauty. "Mit Erstaunen bemerkte Aschenbach, daß der Knabe vollkommen schön war" (30). He is shocked by the "[...] gottähnliche Schönheit des Menschenkindes"

\section{As quoted in Feuerlicht 89.}

81 Reinhard Baumgart, Thomas Mann als Erotischer Schriftsteller" FORUM: Homosexualität und Literatur April 1988: 6. 
(34). Aschenbach is completely spellbound by the lad and compares his beauty to that of "[...] griechische Bildwerke aus edelster Zeit" (30). But even in his enchantment, Aschenbach tries to uncover the less-than-perfect details about Tadzio. He attempts to belittle the object of his passion. Upon closer inspection in a chance elevator ride together, he notices that Tadzio is pale and slim, and that his teeth are gray and sickly, a sign that he will surely die young. By this point in the novella, Aschenbach realizes the youth has captivated him. And to save his soul and his body from that which he fears, namely more immediate contact with Tadzio, he consciously tarnishes his erotic image of the boy. Also, he gets a certain satisfaction and relief from his new-found discovery about the young boy's ill health. Aschenbach believes he can free himself somewhat from the overpowering allure of the youngster by casting him in a negative light. He tries this by using the same art/intellect versus life/flesh dichotomy Mann employed with Ehrenberg.

Gut, gut! dachte Aschenbach mit jener fachmännisch kühlen Billigung, in welche Künstler zuweilen einem Meisterwerk gegenüber ihr Entzucken, ihre Hingerissenheit kleiden (35).

In this particular scene, Aschenbach is enjoying the rapture of Tadzio (whom he calls an Eros) and plays down his erotic enthusiasm. (Hingerissenheit would be a very difficult emotion to contain). In this way, Mann's treatment of Aschenbach and Tadzio mirrors his personal episodes with Ehrenberg. He falsely casts Aschenbach's libidinal state in an intellectual mold. In doing so, he represses homosexual urges (life) with intellectual purpose (art). In his frustration, Aschenbach reveals his homoerotic passion as a seething engine, 
and the alluring Tadzio is the tool set to it - the "Werkzeug einer höhnischen Gottheit." 82 Aschenbach damns dionysus for his confounding and contradictory state.

Taken as a whole, the homoerotic bent of the novella, in contrast to its time of publication in conservative Wilhelmine Germany mirrors the contradiction of sexual desire versus fear in Aschenbach. The controversial theme of homosexual attraction could only be presented if cast in societally acceptable terms - in this case by seizing images of classical Greece. Mann believed he could free himself from the controversial nature of the novella in his myriad allusions to classical Greece. 83 After laying eyes on Tadzio, Aschenbach begins to resource Greek antiquity in describing the impact the boy has on him. He also believes that in neither nature nor in the fine arts has he seen such divine beauty. Tadzio was "[...] von so einmalig persönlichem Reiz, daß der Schauende weder in Natur noch bildender Kunst etwas ähnlich Geglücktes angetroffen zu haben glaubte" (30). And therein lies Aschenbach's sexual contradiction. Aschenbach has never allowed himself to see beauty in nature, because he has suppressed his own natural, erotic connections with nature. And he has never seen such beauty in art, because the type of beauty he is now experiencing cannot be relegated solely to the confines of his intellect. It is also libidinal. Nonetheless, classical art becomes the veil behind which a societally-sanctioned homoerotic element unfolds.

82 Vaget 175.

83 As Feuerlicht asserts "It was more of a help and refuge for Mann, both as the one who had that experience in real life and as the author who had to think of the public's reaction to that experience." The texual information and the quote here appear on pages 93-94. 
Clearly, Mann faced a great deal of societal pressure in publishing Death in Venice. 84 The risk of exposing his own homosexuality weighed heavily on his mind during the conception of the novella. It is now equally clear that he felt Mann had to repress his sexuality. A writer needing to circumvent these barriers - to present a controversial story and still remain safe from reproach - can find deliverance in several ways.85 As mentioned, one safety feature - the main one Mann uses in Death in Venice includes seizing on classical Greek ideology as a kind of paradise, a time and place where homosexuality was accepted. ${ }^{86}$ This is called an arcadian response. ${ }^{87}$ Arcadia is a mythically created place where there is abundance and one can be free. It is a milk-and-honey land. In the case of Death in Venice, Mann alludes to classical Greece in order to lessen the negative impact the homoerotic theme might have. ${ }^{88}$ In the numerous references to mythological figures of classical Greece is where the most permissive

84 Böhm 86 and Vaget 179. These two works, among others, point out the difficulty Mann felt in bringing Death in Venice to the public. Vaget perhaps sums it up best where he writes that the homoerotic motif "[...] erklärt auch, warum er die Novelle während der Arbeit wiederholt eine 'unmögliche' Konzeption nannte - weniger wohl wegen des homoerotischen Themas an sich als wegen des unvermeidlichen, verräterischen Bezugs auf seine Person."

85 Gregory Woods, Articulate Flesh: Male Homo-eroticism \& modern poetry (New Haven: Yale UP, 1987) 1-5. (See also, Kellogg 3). The discussion here is taken from the material in Kellogg and Woods. Later, in chapter two, much material will be drawn from Downing's Myths and Mysteries of Same-sex Love.

86 It should be noted that "homosexuality" as a term was coined in the 19th century. The ancient Greeks really had no specific terminology for same-sex love. This reflects the fact that there was complete integration and assimilation of same-sex love into the general culture. There was no need to create issues surrounding homosexuality, because is simply wasn't an issue.

87 The terminology here is taken from Kellogg. The analysis, however, is not a product of merely one critical work.

88 Feuerlicht 93. In his essay, Feuerlicht writes, "For Mann, who greatly cherished his [experience] with the fourteen-year old boy, it meant raising this experience, the nature of which was frowned upon by his contemporary society, to the level of the beauty, art, philosophy, and religion of the perhaps most glorious period in the history of mankind." 
expression of homosexuality in the novella takes place. ${ }^{89}$ The arcadian response forms a schema for the homoerotic elements of the novella. 90 That Mann, however, did not see the necessity to cloak his writing with any notion of Greek antiquity until after his "personal-lyrical travel experience" to Venice in 1911 further points to covert homoerotic fact. 91 Neither Mann nor his protagonist (given the account of Aschenbach's published works) feels the need to conceal their situation behind associations with Greek antiquity until after the introduction of the homoerotic dilemma, that is until their respective trips to Venice. Aschenbach alludes to Greek antiquity "[...] only later in his stay in Venice, when he has to admit to himself that his admiration of the boy's beauty has degenerated into a frenzied passion."92 In Death in Venice, the classical decoys are frequent. Some are merely references to mythological figures who in some way substantiate the homoerotic feature. Some are larger literary works, including Plato's Phaedrus and Euripides' The Bacchants. Comparing the classical texts and numerous other inferences with Death in Venice reveals their shared notions of same-sex love.

Ample homoerotic images are proffered through Mann's allusions to Plato's Phaedrus. In the text, Aschenbach refers to Tadzio as being like Phaedrus, the object of Socrates' admiration. By using Plato's erotic dialogue between Socrates and Phaedrus, Mann shields himself from being necessarily

89 Kellogg 6.

90 Here I mean "intertextual" in that Mann refers to texts and figures from ancient Greece, hence he employs these items intertextually in Death in Venice.

91 As quoted and analyzed in Feuerlicht 93-94.

92 Feuerlicht 94. 
an advocate of homosexual love - even though the Phaedrus is probably the "[m]ost lyric exaltation of homoerotic love."93 Indeed, the mere reference to Socrates in this context points to homoerotic love.94 In the Phaedrus, three different speeches about love are delivered, one by Phaedrus (which is merely a recitation of an earlier speech by Lysias), and two by Socrates. The image created with the older Socrates and the younger Phaedrus mimicks the situation in Death in Venice, with Aschenbach and Tadzio. While Phaedrus recites Lysias' discourse on love, dionysian thought consumes Socrates. The effect the young friend has on him is the same amorous affliction affecting Aschenbach. When Phaedrus finishes reciting Lysias' speech, Socrates criticizes it as being too staid and sober. He belittles Lysias' speech and contrasts it to the love speeches of Sappho, the most wellknown lesbian poet of Ancient Greece, and finds the latter much better. In this reference, he advocates homoerotic poetry as a higher form of art. After Phaedrus' delivery of Lysias' speech, Socrates decides to impress his young friend and delivers his own speech on the meaning of love. During Socrates' love discourse, his delivery becomes exaggerated and showy, a symbol of the dionysian. 95 Socrates' inspiration to compose is the same inspiration Aschenbach gets from Tadzio's presence. The source of the inspiration is love. During Socrates' speech, he illustrates the passion of the lover for his beloved.

93 Christine Downing, Myths and Mysteries of Same-Sex Love (New York: Continuum, 1989) 259.

94 Herbert Lehnert, Thomas Mann: Fiktion, Mythos, Religion (Stuttgart: Kohlhammer, 1965) 91.

95 William S. Cobb, Plato's Erotic Dialogues (Albany: SUNY Press, 1993) 196. Appears as an editor's note. 
He is driven by a tormenting compulsion that leads him on by giving him continual pleasure from seeing, hearing, touching, and experiencing his beloved through all his senses, so that he delights in serving all his darling's needs. ${ }^{96}$

The obsession Socrates is referring to is the same sort of all-consuming sensation that has overcome Aschenbach. Aschenbach wants only to be near Tadzio. Even his daily writing regiment has taken a backseat to the young beauty.

Aber nach einer Viertelstunde schon fand er es schade, die Situation, die genießenswerteste, die er kannte, so im Geist $\mathrm{zu}$ verlassen und durch gleichgültige Tätigkeit $\mathrm{zu}$ versäumen. Er warf das Schreibzeug beiseite, er kehrte zum Meere zurück[...] (37).

Now that Aschenbach has begun to make a daily routine of enjoying the beach with Tadzio in full view, he finds it increasingly difficult to concentrate on his work. Tadzio has become an addiction for him; whereas his work was always the addiction beforehand. The changeover signals the success of Aschenbach's dionysian side over his apollonian side.

Aschenbach's attempt to rationalize his homoerotic passion for the ravishing Tadzio portrays the battle for control over his soul. To do this he usurps and selectively edits Socrates' disquisition on love in order to make Tadzio into a mere work of art - a sort of cerebral, intellectual apollonian model. But Aschenbach's rational arguments mask his intense erotic

96 Cobb 98. 
obsession over the boy - the irrational dionysian. Aschenbach is temporarily able to keep his attraction to the boy on an aesthetic level. Again, he likens him to an "Eros" made of marble (34). He creates a love image of antiquity, palatable to himself and western society. As long as he can keep Tadzio on the level of a god, an unattainable being, he is safe. $\mathrm{He}$ would then be able to keep his sexual desire in check. But the incident where the Polish Tadzio becomes enraged over the Russian tourists places Tadzio in the realm of mortals and, for Aschenbach, this represents an uncomfortable proximity to his own weaknesses. Tadzio rages upon noticing the boisterous, Russian family on the beach. Their presence disgusts him, and Aschenbach reacts:
Dieser kindische Fanatismus, gerichtet gegen das gutmütigste Stück Leben, - er stellte das Göttlich- Nichtssagende in menschliche Beziehungen, er ließ ein kostbares Bildwerk der Natur, das nur zur Augenweide getaugt hatte, einer tieferen Teilnahme wert erscheinen; und er verlieh der ohnehin durch Schönheit bedeutenden Gestalt des Halbwüchsigen eine Folie, die gestattete, ihn über seine Jahre ernst zu nehmen (37).

Tadzio's metaphorical fall from grace places him within the reach of Aschenbach's earthly passion. His self-control is dependent on his keeping Tadzio in the realm of visual beauty - art. Also, Tadzio appears older, beyond the age of consent, thus giving more license to Aschenbach's longing. The display of anger at the Russian family evokes passion, that which is irrational and uncontrollable, a pure dionysian element. 
Mann's use of Phaedrus highlights Aschenbach's own confusion. He is looking at only a portion of Socrates' meaning of love. For Socrates extols the multi-faceted nature of love. He rejects narrow interpretations of eros, such as that recited by Phaedrus. Socrates counters:

If anyone comes to the halls of poetry without the madness of the Muses, convinced that technique alone will make one a good poet, both the poetry of this man who is in possession of his senses and the man himself will fall short of perfection and be eclipsed by the poetry of those who are mad. 97

Here Socrates is attempting to be all-inclusive in his definition of love. Love is not merely a product of reason or technique in art - a rational Apollo image - it is a trio of Dionysus, Apollo and the individual's will. These are the three parts of every human soul. Socrates goes on to describe these three parts as being two horses, bridled and driven by a charioteer. One horse

has a more beautiful stance, with correct conformation and good development. It carries its neck high, is somewhat hook-nosed and light in color, and it has dark eyes. It is lover of honor conjoined with judiciousness and a sense of what is respectable and is a companion of what is truly reputable. It needs no whip[...].

This is the part of Aschenbach's soul that stresses the rational and deeroticized side. The other part of his soul, however, is a horse that

97 Cobb 103. 
[...] is crooked in conformation, gross, and awkwardly constructed with a thick, shortneck, a flat nose, dark and grey, bloodshot eyes. [emphasis added]

The flat nose is clearly part and parcel of the descriptions of the numerous dionysian apparitions coming before Aschenbach. Here, too, the part of the human soul being described is the dionysian element extent in every individual. This is the part of Aschenbach that yearns for the lovely Tadzio. Socrates goes on to defend the dionysian, saying that because it is divine, it cannot be evil. It is to be respected and given its place.

As Socrates expands the image into a myth it becomes clear that the soul is indeed the union of powers, that it would be a mistake to confuse it with the charioteer (who represents cognition, or that aspect of the self [...]) which those "sound of mind" might claim to be the whole. 98

The trick is to balance the two, to work with the struggle. For in the end, the beloved recognizes the lover as one who has earned his love through this struggle. "The beloved's discernment of the honesty and integrity with which the lover engages this struggle is what leads him to realize that there can be no shame in responding to such a lover's advances." 99 Homoerotic love is not the problem; one must engage the struggle inherent in love, in general, whether homosexual or heterosexual.

\footnotetext{
98 Downing 262.

99 Downing 267.
} 
However, the overwhelming appeal of Tadzio presents problems for Aschenbach that he would just as soon not confront. Aschenbach is finding it increasingly difficult to maintain his intellectual image of Tadzio. Due to his increasing passionate frenzy, Aschenbach decides to vacate Venice. But he makes his decision to part in a confused and anxious state. He is not in his right mind. And later he regrets his rash departure. The chance meeting with Tadzio in the elevator incites his decision to leave the city. Tadzio's physical proximity in the close confines of the elevator has afforded Aschenbach the opportunity to see the "Einzelheiten seiner Menschlichkeit" (39). He is no longer a god, a present representation of Greek antiquity. Tadzio is now more mortal than ever and, hence, presents an even greater sexual magnetism against which Aschenbach knows he is helpless. Aschenbach's psychological demise sends him into panic and brings about his decision to leave the city. He is petrified of what could overcome him if he were to stay near Tadzio. He insists he has to run away quickly. Socrates expresses similar concern in his highly-charged situation with Phaedrus. After giving his first speech on love, Socrates decides to leave the scene before things get out of hand. He knows that his first speech has still suffered under some degree of apollonian restraint.

So, my tale shall suffer whatever it deserves, and I shall cross this stream and depart before you force me to do anything else. 100

100 Cobb 100. 
He has not been completely honest about his feelings. He fears any further discussion on love would convey what he really believes. And he fears the outcome. Aschenbach, like Socrates, must cross the symbolic waters of purification - in the case, the canals of Venice. He must escape the stranglehold that Tadzio has on his emotional state. Concurrent to what Aschenbach believes to be his moral fall from grace is the spread of cholera in Venice. This plague is clearly the metaphor for the degeneration of Aschenbach's psyche. The man's physical state is not only being affected by the contagion, but also by the weather. The climate, in its literal and its metaphorical sense, is making him sick. The cholera, having come like Dionysus from the east, is the plague that the climate has spawned. The east wind, whose symbolism is mentioned earlier, is "ihm höchst schädlich" (40). The temptation of Venice, the psychological madness it represents and the physical sickness it expels is killing him. The leitmotif of Venice's weather is especially revealing when Aschenbach's luggage is fortuitously lost, forcing him to remain in the city. At once, the wind changes and sweeps in off the water - a female/dionysian sign - and lifts his spirits. There is suddenly a renewed sense of hope. The loss of his luggage tunes out to be a god-send and the perfect pretext for returning to the intriguing city. He doesn't have to give the real reason he is so elated about returning. He maintains that a man of his stature can't go anywhere without his personal belongings. So, after making what he believes to have been a most unfortunate and rash decision, he is granted a second chance. He goes back to Venice to be with his beloved Tadzio. He does not care now what happens to him, nor is he 
worried about the plague. He is ready to go back. Aschenbach experiences rapture at the turn of events.

\begin{abstract}
Noch immer, von Zeit zu Zeit, ward seine Brust bewegt von Lachen über dies Mißgeschick, das, wie er sich sagte, ein Sonntagskind nicht gefälliger hätte heimsuchen können (45).
\end{abstract}

Again, as it happens throughout the novella, his homoerotic, dionysian impulses have intervened and continue unrelentingly to direct Aschenbach toward his demise.

In another attempt to cast the irrational in a rational mold, Aschenbach repeatedly ponders the dichotomy represented by Tadzio, and the one discussed by Socrates. He asserts, with Socratic overtones, "Form als Gottesgedanken, die eine und reine Vollkommenheit, die im Geiste lebt und von der ein menschliches Abbild und Gleichnis hier leicht und hold zur Anbetung aufgerichtet war" (50). Aschenbach wants to snatch up this beauty into the realms of the mind. He attempts dramatically to see only the spiritual side of love. But Death in Venice, for obvious reasons, does not really achieve this level of the spirit. Aschenbach fails to confine his feelings for Tadzio in a spiritual realm. Aschenbach repeatedly tries to de-eroticize love in art. He invokes Socratic philosophy when it benefits him, but ignores the erotic elements. For in Phaedrus, Socrates also says to his companion, 
So, my dear boy, one must take these things into consideration and realize that the friendship of a lover does not come from goodwill, but from something like the desire for a satisfying meal. As wolves cherish lambs, so lovers befriend boys.

Mann at least privately advocated the carnal, sexual sources of poetic inspiration, as well. In letters to Otto Grauthoff, he circumvents the sensitive nature of homoeroticism by ironically saying "Im Unterleib liegt doch eine Menge Poesie."101 This special brand of libidinally-induced poetry attests to the sexual inspiration in Mann's works. And to make otherwise sanctioned homoeroticism palatable he said one only need bring "[...] die Hunde im Soutterain an die Kette [...]." By crafting Death in Venice as a renaissance of classical Greek thinking, Mann has reigned in the sexual powers and veiled them with more mainstream erotic images.

Mann systematically uses references from tradition to cloak the homoerotic content on the novella. The homoerotic nature of several traditional figures points to latent homosexual desires. For instance, Aschenbach's reference to Saint Sebastian underscores the novella's theme of homosexual attraction. Aschenbach sees himself as a martyr. But, according to him, the quintessential martyr who stares death in face for what he loves is Sebastian. Sebastian, a third-century Roman soldier, was ordered killed by his lover, Diocletian, when it was revealed that Sebastian was a Christian. 102 Such a reference raises questions about Aschenbach's hidden

101 Both quotes as they appear in Baumgart 46.

102 Hayes 173. 
passions. A homosexual Roman soldier is his ideal martyr. Similarly, Aschenbach's reference to Tadzio as being "den troischen Hirten" further illustrates Mann's use of veiled allusions to homosexuality (52). This reference is to the astoundingly beautiful Ganymede whom Zeus snatched up to be his cup bearer. ${ }^{103}$ But he was not just his cup bearer. A little etymology reveals that Ganymede was clearly Zeus' passive partner in homosexual love. "Ganymede" itself means "rejoicing in virility" or "bright penis".104 The Romans knew Ganymede by the name Catamitus, which is where the English "catamite" comes from. In one of the beach scenes, Aschenbach jealously admonishes Tadzio's playmate on the beach, Jaschu, whom he witnesses kissing Tadzio. Aschenbach is tempted to intervene. He wants to possess the boy for his own.

Aschenbach war versucht, ihm mit dem Finger zu drohen. "Dir aber rate ich, Kritobulos", dachte er lächelnd, "geh ein Jahr auf Reisen (38)!

This citation is from Xenophon's Socrates' Memoires . 105 Kritobulos kissed the son of Alcibiades, whereupon Socrates sternly admonishes him to take leave and travel. Taken together, Mann's targeted blending of Aschenbach's object of desire with various mythological and historical characters associated with same-sex fancy concedes his own sexual bias. Also, his use of traditional figures as a veiled form of presenting the socially unacceptable in

\section{Vaget 174.}

104 Woods 23. In another account Ganymede is said to mean "happy genitals." I believe the former to be more appropriate. See Downing 149 for further information.

105 Vaget 173. 
an acceptable light further reveals homoerotic content. Mann is able to present his homoerotic experience while remaining behind a socially acceptable mask.

The dream sequence performs a similar masking role in Death in Venice. In the dream, otherwise blatant elements of homoerotic desire are camouflaged - this time as a dionysian ritual. In the dream, Aschenbach's rational, apollonian control over his homosexual longings is vanquished. Specifically, the dream sequence represents his enlistment into the tribes of dionysus. He is no longer just a spectator to homoeroticism. The long drawn-out " $u$ " sound during the dream is an unmistakable reference to the same sound Aschenbach perceives when he first hears Tadzio's name being called on the beach. Clearly, the guttural sound in the dream refers to that point in the revelry where the emotions are the highest - the orgasm.

Taken together, the sound is a highly charged sexual metaphor of his passion for Tadzio. The dream eliminates any chance that Aschenbach could further rationalize his sexual appetite for Tadzio.

Although Mann incorporated the classical Greek images as decoys against potential criticism, the decoys serve a dual purpose in his case. They are also accepted versions of the homoerotic within high culture - "aus edelster Zeit" (30). Mann considered homosexual love to be lofty. $106 \mathrm{He}$ also considered same-sex love to be part of a superior culture. He wrote that "[...] something which can include the culturally most creative people cannot be ascribed to the sphere of decay." 107 But the taboo nature of homosexuality in

106 As quoted in Feuerlicht 92.

107 Mann, Werke 8: 504. 
his time did not allow Mann to lead an uncloseted life. Instead, he had to repress his homoerotic longings - or he could travel. Whether it was the island of Sylt, distant world cities, or the Mediterranean, Mann, like Aschenbach, could always count on his trips to afford him some measure of anonymity. For in this anonymity, he could more safely drop his guard and indulge his homoerotic fancy. Death in Venice is a literary manifestation of that homoerotic fancy - of Mann's psycho-sexual dichotomy unfolding in Venice. ${ }^{108}$

That Venice was the venue for Mann's - and Aschenbach's - erotic adventure is not merely coincidental. Venice was, in fact, a destination for homosexuals in turn-of-the-century Europe. Venice was the place for "upper-class men to 'disintegrate' and give into their suppressed homoerotic longings [...]."109 In the novella it is part of a "[...] paradigm of homosexual desire and a clear itinerary in European gay history."110 As such, it was a secretive and "coded representation of desire."111 Using Venice was a way to selectively acknowledge the homoerotic mystique of the novella, so that mostly those in-the-know would discern that element. Conversely, there is Mann's affinity for Venice - where he could almost assuredly indulge his

108 Hans Rudolf Vaget, Thomas Mann: Kommentar zu sämtlichen Erzählungen. (Munich: Winkler Verlag, 1984) 178.

109 Hayes 170. In the English translation of Death in Venice, the city is described as being "gay." Taken as a double-entendre from the English, the term "gay" takes on special meaning here.

110 Robert Aldrich, The Seduction of the Mediterranean: Writing, Art and Homosexual Fantasy. (London: Routledge, 1993) 4. The entire first section of Robert Aldrich's book on homosexual fantasy in the Mediterranean is dedicated to Venice and, specifically, Death in Venice.

111 Aldrich 7. 
homosexual fancy. It seems every time he went there, a diary entry detailing sexual fascination with some unknown male was the result.

Venue plays a pivotal role not only in Death in Venice, but also in Phaedrus. In Phaedrus, the action takes place not inside Socrates' city, but outside the confines of the city - beyond the city wall. Socrates and his young friend escape the rigours of the crowded city and retire under a shady tree that grows on the banks of a cool river. They have sought refuge from the heat. In essence, they have found a place to talk to each other about love. They no longer have to bow to the expectations of civilization. They are free to do as they please - outside the literal and symbolic walls of society. Mann and Aschenbach, too, escape their confines to seek freedom to be themselves. It is away from their homes, their societies where they can pursue their homoerotic desires. The place where the action occurs - the narrative space - plays a crucial role in the unfolding of events.

Narrative space plays an important role in another mythological tale with which Mann's novella shares a great deal, Euripides' The Bacchants. In The Bacchants, Pentheus meets his demise outside his normal surroundings (Cithaeron), as well. He is lured by the wild, lascivious offerings of a dinoysian rite in the mountains. Pentheus seeks license outside the confines of his city. His psycho-sexual dilemma also mimicks that of Mann's protagonist. Specifically, Pentheus' transvesticism as he moves into the fatal dionysian rite parallels (albeit stereotypically) Aschenbach's homoerotic journey to his own death. Here, the dionysian influence manifests itself in Pentheus' effeminate cross-dressing. Dionysus has made Pentheus into a woman, of sorts, blurring the social boundaries of gender and sexuality. 
Pentheus, in Mann's novella appearing as Aschenbach, is visited by numerous dionysian strangers who gradually permit him to release his sexual inhibitions - to release what has been repressed in his soul. The work of dionysus is not to create desire. The dionysian rite is merely an avenue for expressing what lies latent and repressed in the individual. In the case of Aschenbach and Pentheus the repression is clear. And the sexual agitation each suffers ends similarly. In The Bacchants the violence accompanying Dionysus' visit is obvious. The horrific mauling of Pentheus, as well as his willing participation in the eroticism, is all part of the dionysian whole. The god of raw passion does not discriminate between violence, eroticism, or mystery. In Death in Venice Aschenbach's fatal cholera is his mauling that goes hand-in-hand with his homoerotic avarice. In each death, there is a measure of transgression that depicts a movement from the rational to the irrational. 112 Pentheus' body is torn apart and scattered about the earth. Aschenbach's death in treated similarly in that the news of his passing reaches the far ends of the earth by travelling across the wires of the modern telegraph. Each tale is a story of a psychological and physical descent - a story of a man trying to come to grips with his own repressed dionysian impulse.

112 Martha Nussbaum, introduction, The Bacchae of Euripides, by C. K. Williams (New York: Noonday, 1990) XIV-XV. 


\section{CONCLUSIONS}

In analyzing the tragic ending of a latent homosexual in Death in Venice, it must be considered that Mann worked under the oppressive definition of sexuality in Wilhelmine society before World War I. These social confines made it possible to overcome a turn-of-the-century social norm only "[...] by imaginatively realizing its extreme moral consequences."113 The moralizing forces of Wilhelmine society forced Mann to create a character like Aschenbach, "a middle-class intellectual of the turn of the century, not a Nietzsche or a Strindberg, and that is why the infatuation for a boy of fourteen brings about the collapse of the man's values. ... [T] ]he drama of Aschenbach is social."114 There are clearly psychological elements to Aschenbach's dilemma, but social norms strictly limit his reactions to the dilemma. Aschenbach is smitten by Tadzio. He cannot, however, entertain his fancy, because such relationships are forbidden by society. In presenting this homosexual relationship in his novella, Mann characteristically outmaneuvers and circumvents social criticism - he never lets Aschenbach touch the boy, and, in the end, he safely kills off his tormented homosexual. In this way, Mann avoids being an advocate for homosexuality. An advocate would have allowed Aschenbach to realize some homoerotic desire, if not with Tadzio, then with

113 Hayes and Quinby 168-169.

114 Aldrich 7. 
some other, perhaps older, male. Mann, however, resists such a temptation and, instead, shrouds his story with myriad details of Greek homosexuality, camouflaging the homoerotic origin of the novella. Thus, Death in Venice is a tale, cautiously contrived to fit into the society in which it was to be received - a society extremely intolerant of homosexuals. Here, too, the earlier discussion of Phaedrus helps define the social nature of Aschenbach's sublimated homosexuality. The conflict in Phaedrus in one of symbiosis between flesh and spirit, not mutual exclusivity. Sexuality and society were not incompatible in classical Greece. Homosexuality, or homoeroticism, was not a "forbidden passion" for ancient Greeks - it was considered part of the whole. 115 In fact, the Ancient Greeks had no term for homosexuality, because for them it was such an integral part of human sexuality, in general. Aschenbach's use of Phaedrus in justifying his passion for Tadzio is, thus, misapplied. The problem in Phaedrus is "coping with a conflict that is inherent in the emotion itself." 116 Aschenbach's conflict is that of a social taboo, an external force. Socrates' restraint in sexual desire, on the other hand, is imposed from within, by the sexual desire itself - by an "idealism that is born out of sexual desire and which does not exist separately from that desire, but only in conjunction with it."117 Aschenbach's dilemma, like Mann's, is borne of a society, not of forces inherent in the emotion.

Despite the enormous fear Mann felt as a result of his homosexuality, he did manage to take a small step as advocate for German homosexual

\footnotetext{
115 Bridges 41.

116 Bridges 41.

117 Bridges 41.
} 
emancipation. This he did in support of Magnus Hirschfeld's Wissenschaftlich-Humanitäres Committee.

"The Committee's goal was first and foremost legal reform, and its first action was the preparation and circulation of a three-page petition which outlined the scientific and humanitarian reasons for amending Paragraph 175 so that homosexual acts would be punishable only in cases involving coercion, public annoyance, or adult-minor relations."118

Thomas Mann was one of those who signed the petition to be presented to the German parliament. Signing the document was a way for Mann to express his personal convictions. However, there was little danger in doing this. The collection of names accompanying his on the list provided the ideal sanctuary from retribution. After all, many of the names on the list were those of other highly-respected individuals: Gerhart Hauptmann, Rainer Maria Rilke, Richard von Krafft-Ebing, Georg Grosz, Hermann Hesse, among others. ${ }^{119}$ There was safety in numbers. Mann's extreme paranoia and obsession with maintaining his secret identity could be entertained by simply adding his name to an already lofty list of people. In this sense, his signing of the petition for homosexual rights mimicks his stance with Death in Venice. He cautiously cloaks a personal argument in a veil of tradition - this time a tradition of literary and political giants. This way, he didn't have to admit openly to his true feelings. Mann did admit his

118 Steakley, Emancipation 30.

119 Steakley, Emancipation 65. 
concerns over his stealth existence to a few of his closest allies. In a letter to his friend and confident, Otto Grautoff, he once contemplated,

What am I suffering from? From knowledge - is it going to destroy me? What am I suffering from? From sexuality

- is it going to destroy me? ${ }^{120}$

Unlike his protagonist Aschenbach, Thomas Mann was not destroyed by his sexuality. However, his life was wracked with the tension between his homoerotic desires and the aggravating restraints placed upon them. This tension is the psycho-social milieu in which Death in Venice exists.

120 Kellogg 7. 


\section{WORKS CITED}

Aldrich, Robert. The Seduction of the Mediterranean: Writing, Art and Homosexual Fantasy. London: Routledge, 1993.

Baumgart, Reinhard "Thomas Mann als Erotischer Schriftsteller," Forum:

Homosexualität und Literatur (April 1988): 5-22.

Baumgart, Reinhard. Glücksgeist und Jammerseele: Über Leben und

Schreiben, Vernunft und Literatur. Munich: Carl Hanser Verlag, 1986.

Berendsohn, Walter A. Thomas Mann: Künstler und Kämpfer in bewegter Zeit. Lübeck: Max Schmidt-Römhild, 1965.

Bolduc, Stevie Anne. "A Study of Intertextuality: Thomas Mann's Tristan and Richard Wagner's Tristan and Isolde." Bulletin of the Rocky Mountain Modern Language Association 37 (1983): 82-90.

Böhm, Karl Werner. Zwischen Selbstzucht und Verlangen: Thomas Mann und das Stigma Homosexualität. Würzburg: Königshausen \& Neumann, 1991.

Bridges, George. 'The Problem of Pederastic Love in Thomas Mann's 'Death in Venice'." Selecta: Journal of the Pacific Northwest Council on Foreign Languages 7 (1986): 39-46.

Cobb, William S., trans. Plato's Erotic Dialogues. Albany: State University of New York Press, 1993. 
de Mendelssohn, Peter, ed. Tagebücher, 1918-1921: Thomas Mann.

Frankfurt a. M.: Fischer, 1979.

de Mendelssohn, Peter, ed. Tagebücher, 1933-1934: Thomas Mann.

Frankfurt a. M.: Fischer, 1977.

de Mendelssohn, Peter, ed. Thomas Mann: 1875-1975. München: Moos

Verlag, 1975.

Downing, Christine. Myths and Mysteries of Same-Sex Love. New York:

Continuum, 1989.

Feuerlicht, Ignace. "Thomas Mann and Homoeroticism." The Germanic

Review LVII, 3 (Summer 1982): 89-97.

Gabriele, Seitz. Film als Rezeptionsform von Literatur: Zum Problem der

Verfilmung von Thomas Manns Erzählungen "Tonio Kröger,"

"Wälsungenblut," und "Der Tod in Venedig". Munich: tuduv-

Verlagsgesellschaft, 1979.

Hadas, Moses and John McLean, trans. Ten Plays by Euripides. New York:

Bantam, 1960.

Hamburger, Michael. Contraries: Studies in German Literature. New York:

E. P. Dutton \& Co., 1970.

Hayes, Tom and Lee Quinby. "The Aporia of Bourgeois Art: Desire in

Thomas Mann's 'Death in Venice'." Criticism: A Quarterly for

Literature and the Arts 31.2 (Spring 1989): 159-177.

Hiller, Kurt. "Wo bleibt der homoerotische Roman?" Jahrbuch für sexuelle

Zwischenstufen 14 (1914).

Isemann, Bernd. Thomas Mann und der 'Tod in Venedig': Eine kritische

Abwehr. München, 1913. 
Jens, Inge, ed. Tagebücher, 1944-1.4.1946: Thomas Mann. Frankfurt a. M.: Fischer, 1986.

Jowett, Benjamin, trans. On Homosexuality: Lysis, Phaedrus, and Symposium. Buffalo: Prometheus Books, 1991.

Kaufmann, Walter, trans., The Birth of Tragedy and the Case of Wagner.

New York: Vantage, 1967.

Kellogg, Stuart, ed. Literary Visions of Homosexuality. New York: Haworth Press, 1983.

Lehnert, Herbert. Thomas Mann: Fiktion, Mythos, Religion. Stuttgart:

Kohlhammer, 1968.

Lowe-Porter, H. T., trans. Death in Venice and Seven Other Stories. New

York: Vintage Books, 1954.

Mann, Thomas. Der Tod in Venedig. Frankfurt: Fischer, 1954.

Mann, Thomas. Gesammelte Werke in dreizehn Bänden. 13 vols.

Frankfurt am Main: S. Fischer, 1961-1974.

Mádl, Antal and Judit Györi, ed. Thomas Mann und Ungarn. Köln-Wien: Böhlau Verlag, 1977.

Nussbaum, Martha. Introduction. The Bacchae of Euripides. by C. K.

Williams. New York: Noonday Press, 1990.

Praetorius, Numa. "Mann, Thomas: Der Tod in Venedig. Novelle"

Jahrbuch für sexuelle Zwischenstufen (1919).

Reich-Ranicki, Marcel. Thomas Mann Und Die Seinen. Stuttgart: Deutsche Verlags-Anstalt, 1987.

Steakley, James D. The Homosexual Emancipation Movement in Germany. Salem, New Hampshire: Ayer, 1975. 
Strachey, James. Civilization and its Discontents. New York: W. W. Norton \& Co., 1961.

Vaget, Hans Rudolf. Thomas Mann: Kommentar zu sämtlichen

Erzählungen. Munich: Winkler Verlag, 1984.

White, Richard. "Love, Beauty, and 'Death in Venice'." Philosophy and

Literature 14.I (April 1990): 53-64.

Winston, Richard and Clara Winston, trans. Diaries, 1918-1939: Thomas

Mann. London: A. Deutsch, 1983.

Woods, Gregory. Articulate Flesh: Male homo-eroticism \& modern poetry.

New Haven: Yale UP, 1987. 